\title{
A Socialidade contra o Estado: a antropologia de Pierre Clastres ${ }^{1}$
}

\author{
Gustavo Baptista Barbosa
}

Mestre em Antropologia Social - Museu Nacional (UFRJ)

RESUMO: Clastres promove uma "dessubstancialização" do Estado, que não é "o Eliseu, a Casa Branca, o Kremlin", mas um "acionamento efetivo da relação de poder". Não há por que acreditar, então, que ele tenha, num pudor durkheimiano, reificado a sociedade. Ainda que não recorra ao conceito, parece-nos que existe já socialidade em Clastres: a socialidade contra o Estado, portanto. Ao explorar, nas três partes deste estudo, a maneira como Clastres encara a "sociedade", o "Estado" e o "contra", acreditamos que, com o auxílio de sua etnografia, encontramos indicações de como enfrentar alguns dos impasses da antropologia; como o de abandonar o individualismo metodológico sem cair num holismo transcendental e vice-versa; o de construir modelos de intencionalidade sem sujeitos; o de pensar a relação social sem, por esta démarche, implicar necessariamente a existência da "sociedade"; e, finalmente, o de mostrar como a "objetividade" da socialidade pode operar por meio da "subjetividade" das pessoas-em-interação.

PALAVRAS-CHAVES: teoria antropológica, antropologia política, Pierre Clastres, socialidade. 
Gustavo B. Barbosa. A Socialidade contra o Estado...

\section{Por um Shakespeare menor}

Carmelo Bene gosta dos perdedores. Ao reescrever dois clássicos de Shakespeare - Romeu e Julieta e Ricardo III - procede à "cirurgia"2 semelhante. Num caso, "amputa" prematuramente o galante Romeu da história original; no outro, todos os influentes personagens masculinos, à exceção do próprio Ricardo III. Como resultado, sai de cena, literalmente, o Poder, o das famílias em Romeu e Julieta, e o do aparelho de Estado, em Ricardo III. Ao conceder "tratamento menor" (Deleuze e Bene, 1978, p. 96) ao "dramaturgo maior", Bene desencadeia potencialidades que permaneciam inexploradas nas tragédias de Shakespeare, porque algo sempre existe nas aparentes ausências.

Como dar "tratamento menor" a um "autor maior", de forma a desvelar potencialidades inexploradas em suas obras, devires precocemente abortados? Deleuze fornece a "fórmula", ao evidenciar as conseqüências da dramaturgia de Bene: começa-se por extirpar todos os elementos de poder - na língua, nos gestos, na representação, no representado. Abole-se a História, "marcador temporal do Poder", e extingue-se a estrutura, seu "marcador sincrônico, conjunto de relaçôes entre invariantes" (idem, p. 103). O que sobra? Tudo, responde Deleuze. Assim, "operação por operação, cirurgia contra cirurgia, concebe-se [...] como 'minorar' (termo empregado pelos matemáticos), como impor um tratamento menor ou de minoração, para extrair devires contra a História, vidas contra a cultura, pensamentos contra a doutrina, graças e desgraças contra o dogma" (idem, p. 97).

Qual o sentido de "minorar" um autor já "menor"? Na verdade, "menor" e "maior" não designam características intrínsecas dos autores, mas "operações", "cirurgias" a que seus textos são submetidos (Goldman, 1994, p. 32; Vargas, 2000, p. 260). Conforme raciocinam Deleuze e Guattari para as línguas, mesmo o inglês, apesar de sua ambição univer- 
salista, presta-se a usos "menores", e o black-english e todos os americanismos de gueto corrompem-lhe as constantes e a pretensa homogeneidade (Deleuze e Guattari, 1980, vol. 2, p. 47-48; Deleuze e Bene, 1978, p. 98-102). Contudo, não raro, os dogmas e regras da "régia ciência" (Deleuze e Guattari, 1980, vol. 5, p. 26) e as mesquinhas exigências de nossos "marcos teóricos" inibem as "leituras menores", possíveis mesmo no caso de autores considerados "maiores". A utilização disciplinadora de seus textos mais reconfortantes afastará qualquer ameaça desestabilizadora: que nos seja dado o bálsamo alentador do positivismo de As estruturas elementares do parentesco, em vez do inquietante e fluido método de "rosácea" do Mythologiques. Entende-se, perfeitamente, que tanto mais esforço seja desprendido na domesticação dos "autores menores". Se incomodam os cânones de nossa "régia ciência", que se os submeta às assépticas leituras corretivas para que possamos dormir tranqüilos. Infelizmente, há aqueles que sofrem de aguda insônia.

Qual o sentido do retorno à obra de Clastres? A pergunta lembra outra, que se repete mil vezes para quem lê Mille Plateaux, com a cadência de um ritornelo: "por que voltar aos primitivos, quando se trata de nossa vida" (idem, vol. 3, p. 84)? François Châtelet fornece elementos para a resposta ao afiançar a absoluta contemporaneidade do estudo da história da filosofia. A referência ao passado - assevera - permite uma dessacralização e uma desmitologização dos discursos atuais do poder (Châtelet, 1976, p. 34). Em suma: uma desterritorialização.

Se a antropologia terá sempre procurado conjurar a perpétua ameaça do evolucionismo, isto não a impediu de lançar sobre a própria história olhar tipicamente evolucionista (Goldman, 1999, p. 9), como se as idéias nascessem, amadurecessem e perecessem e pudessem ser asseadamente 
Gustavo B. Barbosa. A Socialidade contra o Estado...

organizadas em escaninhos: evolucionismo; funcionalismo; estruturalfuncionalismo; estruturalismo; fragmentação contemporânea etc. Contudo, as idéias não morrem. "Não que elas sobrevivam a título de arcaísmos" - ensinam Deleuze e Guattari. "As idéias sempre voltam a servir, porque sempre serviram, mas de modos atuais os mais diferentes" (1980, vol. 4, p. 14). Trata-se, portanto, de levar o exercício antropológico suficientemente a sério de maneira a viabilizar um olhar etnológico também sobre a história da disciplina, capaz de registrar diferenças e de registrá-las precisamente para nós e para nossa atualidade (Goldman, 1994, p. 23-4). É o que Châtelet recomenda para a história da filosofia: "a referência ao passado permite-nos pensar nossa atualidade (e quem sabe: imaginar nosso futuro) através do diferencial" (1976, p. 40; grifo do autor). Dessa maneira, "conceitos elaborados em circunstâncias históricas específicas - quer dizer, durante lutas intelectuais (políticas) datadas, inseridas em estruturas mentais distintas das nossas e dispondo de códigos diferentes - (...) podem ser importados a uma outra época, para outro sistema de racionalidade, e permanecerem operantes, constituindo fatores de inteligibilidade decisivos" (idem, p. 51). Uma genealogia das idéias como crítica da atualidade ganha então sentido: a démarche sugerida por Châtelet permite, a um só tempo, a compreensão dos enunciados filosóficos, das regras de produção precisas, datadas, que lhes deram origem, e um distanciamento da realidade em que estamos imersos, para a qual importaremos conceitos que funcionarão como grades de inteligibilidade e, eventualmente, norte para a atuação política (idem, p. 49 e 52). Uma "visão espacial" da filosofia, que faz com que a história se transmute em geografia das idéias.

Os conceitos podem, assim, ser desenraizados, desterritorializados e reterritorializados mais à frente, fornecer grades de inteligibilidade em outras realidades e outros autores. O próprio Clastres nos havia sugerido caminho semelhante, em artigo em que expõe o paradoxo da etno- 
Revista de Antropologia, São Paulo, USP, 2004, v. 47 no 2.

logia e o que constitui sua única saída: "Entre o silêncio e o diálogo" (1968b). A etnologia nasce como ciência caudatária de certo humanismo, cuja "razão" recusou a aliança com as "linguagens estranhas" dos loucos e dos selvagens: Artaud entre os Tarahumara (idem, p. 35). Define-se, entretanto, como saber sobre aquilo que se preferiria ver excluído:

O paradoxo da etnologia é que ela é, a um só tempo, ciência e ciência dos primitivos; que, absolutamente desinteressada, ela realize, melhor do que qualquer outra atividade, a idéia ocidental de ciência, mas escolhendo como objeto aquilo que se encontra mais distante do Ocidente: o surpreendente é, finalmente, que a etnologia seja possível! (idem, p. 36)

Se o é, há um preço: o de afirmar-se como um discurso sobre os primitivos, carregando consigo toda a arrogância "daquilo que o século XIX produziu de mais bobo, o cientificismo" (Clastres, 1978, p. 167). Como os paradoxos corrompem-lhe, de dentro, a organicidade, deve-se procurar a fuga viável: como única "ponte" lançada entre o Ocidente e os selvagens por ocasião da trágica partilha, cumpre à etnologia evitar discursar sobre os primitivos e procurar estabelecer, com eles, um diálogo (Clastres, 1968b, p. 37). Saem de cena os etnólogos distanciados, ditando, desde Sirius, regras de casamento, tabus alimentares e normas de evitação social para "seus" nativos. Não mais supostas metaperspectivas, geometrais, ponto de vista dos pontos de vista, de onde olharia para "suas" sociedades o antropólogo, orgulhoso. Como diálogo, a antropologia se faz junto, com, ao lado de. É ponte - e de mão dupla. Imersos nas formas-Estado, compreenderemos facilmente que as sociedades indígenas recorram a poderosos mecanismos para inibir o pleno desenvolvimento delas - que já estão lá e atuam, presentes na aparente ausência. Da mesma forma e inversamente, as sociedades indígenas nos concederão as grades de inteligibilidade para que compreendamos a atuação das 
Gustavo B. Barbosa. A Socialidade contra o Estado...

forças anti-Estado entre nós, inibidas e, contudo, presentes na aparente ausência. Tudo estará em tudo e reciprocamente, na feliz expressão de Donzelot (apud Carrilho, 1976, p. 155): Estado entre os indígenas; antiEstado entre nós; Clastres nos dilemas da antropologia contemporânea e às avessas.

Nenhum autor é único; tampouco Clastres o será. Conhecem-se as ilusões e os riscos da "função-autor" (Foucault, 1969), que transforma o escritor em unidade; sua obra em unidade; num e noutro caso, ilhas isoladas, Trobriands eternizadas, à espera de biógrafo que lhes traduza o equilíbrio. Nem obra nem autor são mônadas fechadas e auto-suficientes, e as contextualizações excessivas - como bem lembra Vargas - "acantona[m] as idéias na época e no lugar em que surgiram" (2000, p. 27) e inibem os enxertos, que farão com que os mesmos conceitos polinizem territórios outros.

A etnografia de Clastres insinua-nos linhas de fuga para alguns dos dilemas da antropologia contemporânea. Se a lingüística de Sapir e Whorf terá sugerido certa "semântica da cultura" - como se existisse correlação necessária entre estruturas lingüísticas e culturais - e a de Saussure e Trubetzkoy terá inspirado uma "sintática da cultura" - com língua e cultura sendo vistas como atualizações de regras imanentes que presidiriam à organização de ambos os sistemas -, Clastres nos oferece uma escapatória, sob uma terceira modalidade: a de uma pragmática da cultura. "Deste terceiro ponto de vista," - escreve Goldman - "não se trata de encarar os códigos a partir de sua organização interna (privilégio da sintaxe), nem de analisá-los segundo suas relaçôes com os referentes aos quais remetem (privilégio da semântica), mas de buscar os modos específicos através dos quais esses códigos são atualizados, joga- 
Revista de Antropologia, São Paulo, USP, 2004, v. 47 no 2.

dos ou manipulados na realidade concreta de cada sociedade particular - uma espécie de 'pragmática', portanto" (1999, p. 20).

Não que Clastres se deixe fetichizar por certa concepção da "pessoa" como indivíduo, inexistente entre os Guayaki. Ao identificar a preocupação com a práxis como característica que se acentua nos estudos dos antropólogos a partir da década de 1980 - conferindo-lhes, eventualmente, certa unidade -, Ortner não se nega a apontar as dificuldades evidentes - e não resolvidas - daí decorrentes, que advêm precisamente da natureza da interação entre a "prática", de um lado, e o "sistema", do outro (1984, p. 144 et passim). De fato, como a "prática" engendra o "sistema" e como o "sistema" engendra a "prática"? Encontramo-nos, ao final, sempre diante das mesmas dicotomias, dos mesmos pares eternamente julgados excludentes: a "sociedade todo-poderosa", de um lado, o "indivíduo manipulador", de outro. Contudo, como aponta Ortner, "o estudo da prática não constitui alternativa antagonista ao estudo dos sistemas ou estruturas; é-lhes, antes, o complemento necessário" (idem, p. 146 e 147). Não o "sistema" ou a "prática"; mas o "sistema" $e$ a "prática".

$\mathrm{Na}$ "pragmática" Guayaki, Clastres encontra a linha de fuga para o paralisante dualismo "indivíduo" e "sociedade" . O desafio parece ser precisamente este: como construir modelos de intencionalidade sem sujeitos? Como não personificar a sociedade, fazendo dela um megasujeito? Como sair do individualismo metodológico sem cair em certo holismo transcendental ou vice-versa? Há como pensar relação social sem sociedade? Ou alternativamente, em termos que se aproximam mais da discussão que travaremos a seguir: como a "objetividade" da socialidade opera por meio da "subjetividade" das pessoas-em-interação? 
Gustavo B. Barbosa. A Socialidade contra o Estado...

Como Bene, também nós gostamos dos "perdedores".

Não pretendemos, assim, discutir a legitimidade das leituras que os detratores costumam fazer da obra de Clastres: são leituras, sem dúvida, perfeitamente válidas; não necessariamente as mais interessantes, entretanto. Terá, de fato, havido certa tendência a banir a obra de Clastres para degredado escanteio, a extirpá-lo do corpus da régia ciência - que terá suas exigências e sua política (Deleuze e Guattari, 1980, vol. 5, p. 24 et passim) -, e a transformá-lo em "autor menor", num "perdedor". Em certo sentido - irônico, claro -, levaremos essa tendência ao paroxismo: o degredo vai desterritorializá-lo, permitindo que o recuperemos em nova perspectiva, livre já da camisa-de-força da leitura estritamente durkheimiana. Por isso, vamos "minorá-lo" ainda mais e extirpá-lo de um de seus conceitos centrais - o de "sociedade". Não tanto, evidentemente, porque aspiremos convertê-lo em "ganhador", mas simplesmente porque as "regras do jogo" parecem destituídas de sentido.

Libertada dos constrangimentos do conceito de "sociedade" à durkheimiana, que alguns analistas insistem em impingir-lhe, a obra de Clastres vai bascular - como as tragédias de Shakespeare, emancipadas de Romeu e dos poderosos personagens masculinos de Ricardo III. Basta que selecionemos outras passagens e outros desenvolvimentos que aqueles que sustentam as abordagens tradicionais e identificaremos nos escritos de Clastres potencialidades insuspeitas - por exemplo, certa concepção de "socialidade", na acepção mesma emprestada pela recente antropologia britânica ao termo (Gell, 1999; Ingold, 1996, p. 55-98; Strathern, 1988) -, que, na verdade, sempre estiveram lá, presentes na aparente ausência ${ }^{4}$.

Trata-se, enfim, de leitura, se não obrigatoriamente interessante, ao menos interessada de Clastres. A qual assumidamente terá boa vontade para com o autor. Uma leitura política, sem dúvida. Todas são. 
Revista de Antropologia, São Paulo, USP, 2004, v. 47 no 2.

Há um Clastres-sociólogo, um Clastres-filósofo político, um Clastres em devir-etnógrafo. Simultânea e reciprocamente, o que faz com que se ressinta de acentuada artificialidade a divisão deste artigo em partes 5 .

A primeira parte deste estudo fez genealogia. Vistoriou a tradição e exigiu precauçôes: a ciência régia esteve sempre à espreita. Procuramos mapear brevemente as transmutações (Châtelet, 1976, p. 52) por que passou o conceito de "sociedade" no horizonte das obras de Durkheim e Lévi-Strauss ${ }^{6}$. Nossa aposta: a de que o saudável exercício de Clastres de "aproximação e afastamento" para com Lévi-Strauss não implica um restabelecimento de Durkheim.

Quando a genealogia ameaçava converter-se em arborescente estrato (Deleuze e Guattari, 1980, vol. 1, p. 54, 88 e 89), empreendemos a primeira fuga e abortamos a raiz, convertendo-a em radícula: voltamonos para o que há de filósofo-político em Clastres. Na verdade, o tratamento que ele reservará ao "Estado" permite-nos desterritorialização complementar de seu conceito de "sociedade". O Estado, afirma Clastres, "não é o Eliseu, a Casa Branca, o Kremlin" (1978, p. 166), mas o "acionamento efetivo da relação de poder" (1976b, p. 115): é o que nos faculta, por exemplo, afiançar que haverá Estado entre os primitivos, presente na aparente ausência.

A esta altura, a terceira fuga, rizomática, impôs-se: "o rizoma é uma antigenealogia" (Deleuze e Guattari, 1980, vol. 1, p. 20). Ao colocar a concepção de Clastres sobre o Estado contra sua acepção para a sociedade, um e outro conceito se desenraízam e podemos ver, em ambos, conjuntos de relaçôes: socialidades, máquinas de subjetivação sem nenhuma externalidade com relação às pessoas que engendram e que as engendram. Identificando no que Clastres "não diz e que está entretanto presente no que diz" (Deleuze apud Goldman, 1994, p. 379), reencontraremos, no desenlace deste trabalho e ao longo de toda sua obra, sua etnografia. 
Gustavo B. Barbosa. A Socialidade contra o Estado...

\section{Raízes: a "Sociedade" em Clastres, Durkheim e Lévi-Strauss}

Durkheim contribuiu para certa canonização de uma forma-Estado de pensar em sociologia. Deleuze e Guattari recordam que, no Timeu, Platão opôs dois modelos de ciência - um do Idêntico e do Uniforme, outro do Devir - apenas para, muito ligeiramente, descartar-se do segundo (1980, vol. 5, p. 36). O primeiro modelo, legal e legalista, põe as constantes em evidência, raciocina por teoremas e axiomas e pretende subtrair as operações das condiçõos da intuição, a fim de convertê-las em "conceitos" e "categorias": trata-se da ciência régia, forma-Estado de pensar. Contudo, haverá sempre "um palestino, [...] um basco e um corso" (idem, vol. 3, p. 94) a desafiar a segurança assim adquirida, e o segundo modelo operará antes com variáveis do que com constantes, raciocinará por problemas e, ao invés de ocupar-se do estável, do eterno e do idêntico, optará pelos devires e heterogeneidades e, às essências, preferirá acontecimentos, acidentes e transmutaçôes. Os "binarismos acabados" - dom e mercadoria; status e contrato; Gemeinschaft e Gesellschaft; racionalidade afetiva e racionalidade instrumental; solidariedade mecânica e solidariedade orgânica; indivíduo e sociedade -, verdadeiros pontos de parada, tão característicos da ciência de Estado, terminam, nesse segundo caso, descartados em nome de uma lógica dos fluxos, que passa entre os pontos, intermezzos em contínuo movimento. Contrariamente a isto, porém, foi o privilégio concedido por Durkheim às grandes representações coletivas, binárias, ressonantes e sobrecodificadas que fizram escola (idem, vol. 3, p. 98).

Em $A$ sociologia francesa, Lévi-Strauss demonstra como todo o sistema durkheimiano pode ser remetido ao par indivíduo/sociedade (1947, p. 527 et passim). Estorvado por antinomias de uma ponta a outra - o finalismo da consciência versus a cegueira da história; a sociologia versus 
Revista de Antropologia, São Paulo, USP, 2004, v. 47 no 2.

a psicologia; o sentido lógico das "origens" e das "formas elementares" versus o genealógico; as regras morais versus os apetites sensuais; os conceitos versus as sensações; o sagrado versus o profano (Lukes, 1973, p. 16 et passim) -, o edifício durkheimiano procura vencer as inevitáveis ambigüidades daí decorrentes por meio da determinação de níveis intermediários na realidade coletiva (Lévi-Strauss, 1947, p. 527). Recusa, veementemente, entretanto, adotar atitude semelhante no plano individual. Será precisamente a delimitação de tais níveis intermediários como o do pensamento inconsciente -, todavia, que, na opinião de LéviStrauss, facultará a transposição da aparente oposição indivíduo/sociedade. Negando-se a encarar a questão de frente, Durkheim perseverará na ambivalência do par, que perpassará toda a sua construção teórica.

A distinção indivíduo/sociedade constituía, na realidade, instrumental especialmente oportuno na empreitada de Durkheim de definição de domínio autônomo para a sociologia. Buscava-se tal independência particularmente diante da psicologia e da filosofia. Operando uma série de substituições epistemologicamente inócuas (e plenas de consequiências nos planos ontológico e político) (Vargas, 2000, p. 140), Durkheim procurou livrar seus raciocínios de noções metafísicas até então em voga - como Deus ou os a priori kantianos -, recorrendo a conceitos que lhe pareciam revestidos de maior cientificidade: as categorias da lógica e as idéias de Deus e totalidade passarão a ter, então, matrizes extralógicas ou, mais propriamente, sociológicas. É a sociedade - argumenta - que se encontra na raiz dos sistemas classificatórios, de conceitos como os de totalidade e divindade e das concepções filosóficas clássicas. A conquista de domínio pretensamente autônomo para a sociologia no campo dos saberes científicos demandava, porém, preço elevado: o da cisão radical entre indivíduo e sociedade e o da prevalência - imperial - desta sobre aquele, inaugurando tradição cujas dificuldades a antropologia 
Gustavo B. Barbosa. A Socialidade contra o Estado...

herdaria por inteiro e das quais apenas muito recentemente vem adquirindo consciência e buscando libertar-se (Viveiros de Castro, 1996, p. 518 e 521; Ingold, 1996, p. 57 et passim).

Chave explicativa para tudo, a "sociedade" em Durkheim termina assim naturalizada e permanece, ela própria, inexplicada. Como bem observa Gianotti, recuperado por Vargas (2000, p. 158), no fundo, não há qualquer diferença epistemológica entre o Deus dos espiritualistas e a "sociedade" de Durkheim: todos dois constituem o fundamento último a atribuir racionalidade a tudo e para além dos quais nenhuma pergunta se justifica. Há, dessa maneira, marcada ironia em que o sociologismo extremado de Durkheim dependa visceralmente de sua excrescência, o indivíduo. Não poderia ser de outro modo, aliás: a dificuldade advém precisamente da suposição de que tais entidades - indivíduo e sociedade - existam e levem vida independente, autônomas e externas uma com relação à outra. A "sociedade" de Durkheim trai os objetivos emancipacionistas que o estudioso entressonhava para sua disciplina. Impura - como não poderia deixar de sê-lo -, dependerá dos indivíduos, porque terminará, ela própria, pensada como um mega-sujeito: dotada de vontades, de uma consciência, de uma personalidade, de um ser. De alma, inclusive (Lukes, 1973, p. 11, 236, 523 e 526). E, surpreendentemente, destituída de vida. É Van Gennep quem escreve:

Temo que M. Durkheim, apesar de seu aparente respeito pelos dados etnográficos, possua apenas apreço pelas concepções metafísicas e, ainda mais, escolásticas; ele atribui verdadeira realidade a conceitos e palavras. Privado do significado da vida - quer dizer, do sentido biológico e etnográfico -, ele transforma entidades vivas em plantas cientificamente dissecadas, como num herbário. (apud Lukes, 1973, p. 526-7)

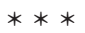


Revista de Antropologia, São Paulo, USP, 2004, v. 47 no 2.

Um plano pode apontar em duas direções (Deleuze e Guattari, 1980, vol. 4, p. 54-5). Em sua primeira versão, o plano permanece oculto. A cada instante, faz com que o dado seja dado, mas o plano, ele próprio, esconde-se e nada mais se pode fazer a não ser inferi-lo ou induzi-lo simultânea ou sucessivamente, em sincronia ou diacronia - a partir daquilo que ele concorda em desvelar. Teleológico, funciona como um princípio mental, sempre numa dimensão suplementar $(\mathrm{n}+1)$ àquilo que efetivamente revela. Plano de transcendência por excelência: "[p]ode estar no espírito de um deus, ou num inconsciente da vida, da alma ou da linguagem" (idem, p. 54). Na segunda versão do plano, não mais existem formas ou desenvolvimentos de formas, sujeitos ou formação de sujeitos, estruturas ou gêneses, mas apenas relações de movimento e repouso, de velocidade ou lentidão de elementos ainda não - ou jamais - formados. Plano de imanência por excelência, não se conhecem aí senão longitudes e latitudes, velocidades e hecceidades, afectos e individuaçôes sem sujeitos a constituírem agenciamentos coletivos (idem, p. 55).

O estruturalismo de Lévi-Strauss depende fundamentalmente de um plano de transcendência. Ao procurar contornar as dificuldades das proposições de Durkheim sobre as origens sociais do simbolismo e substituí-las pela tese das fundações simbólicas do social, Lévi-Strauss recorrerá à noção de inconsciente. As obrigações de dar, receber e retribuir, as trocas concretas e seus cimentos místicos e afetivos (Lévi-Strauss, 1950, p. XLVI), rochas da vida social em Mauss, passam em Lévi-Strauss à condicão de aparências, a denunciar a operação, num plano mais profundo, do inconsciente. Nas trocas, quer Lévi-Strauss, há mais do que as coisas trocadas $(1967$, p. 520): como reflexos da operação do princípio de reciprocidade, as trocas testemunham, no domínio cultural, uma estruturação natural inconsciente, responsável pela emergência do pensamento simbólico (Simonis, 1968, p. 35). Troca, reciprocidade e comunicação - em níveis crescentes de abstração - ocuparão posição central 
Gustavo B. Barbosa. A Socialidade contra o Estado...

no edifício teórico de Lévi-Strauss na medida em que permitirão ultrapassar a contradição inerente ao pensamento simbólico, a percepção do mesmo como pertencendo a si e a outrem, e viabilizarão o "diálogo" entre os dois. Estão aí as bases para um novo humanismo, que torna possível o próprio exercício antropológico.

Mas quais são, então, as condiçóes de possibilidade desta antropologia, preocupada, kantianamente, com as condições de possibilidade da vida em sociedade? O que, para funcionar, ela se vê obrigada a excluir? Há aí uma relação bastante particular com a etnografia, transformada em ferramenta de acesso ao universal inconsciente. A liturgia de LéviStrauss sugere um círculo, em seu duplo raciocínio progressivo e regressivo: na diversidade cultural concreta, deve o analista buscar as constantes que lhe insinuem o sistema da estrutura social estudada (idem, p. 170 et passim). A investigação não termina aí, porém, uma vez verificadas as constantes, pode o estudioso pensar a diversidade cultural e extrair dela os pares constitutivos, cuja relação, de oposição, caracterizará a estrutura do inconsciente. $\mathrm{O}$ fechamento do círculo estaria a exigir, entretanto, o retorno ao concreto vivido. Aí contudo algo se perde - porque algo sempre se perde - e o retorno deixa de ser eterno.

Perdem-se a história, o tempo - que não chega a ser reencontrado -, o vivido. Pouco adianta, porém, tentar anestesiar os efeitos evidentes da etnografia, transformando seus dados em mera manifestação de um inconsciente estrutural - forma de ultrapassar, mas tão-somente neste plano, as antinomias do durkheimianismo, especialmente entre indivíduo e sociedade - e remetendo-a às matrizes binárias cerebrais que fazem do homem Homem e submergem a cultura na natureza. Dessa forma, o homem termina, realmente, nu. Tal procedimento, entretanto, desnuda também, em alguma medida, o rei. 
Revista de Antropologia, São Paulo, USP, 2004, v. 47 no 2.

"Nu como um verme", à exceção "[d]as botas - não teria podido andar descalço e temia as serpentes - e [de] um grosso cinturão de couro que sustentava meu 38 na bainha. [...] Foi com esse bizarro equipamento que eu prossegui a marcha" (Clastres, 1972, p. 146). Assim Clastres relata sua decisão de livrar-se das roupas, quando imergia na floresta junto com um grupo de indígenas. Ao aperceber-se de que sua indumentária constituía um estorvo a inviabilizar passos acelerados como os de seus companheiros, Clastres decide-se pelo desnudamento. Há aí um certo devir-indígena do etnólogo, condição de possibilidade de uma antropologia que não elabora discursos sobre a alteridade, mas que se constrói a meio-caminho, eterno intermezzo, esforço sempre renovado de desterritorialização que faz com que sejamos estrangeiros não apenas em terra estranha, mas também, em sentido ainda mais radical, em nossa própria terra.

A centralidade reconhecida à etnografia em sua obra - conforme magistralmente ilustrado pelo Crônica dos indios Guayaki - explicará o paulatino desenraizamento em relação a Lévi-Strauss. Se Clastres começa onde Lévi-Strauss havia parado - com os homens nus (Verdier in Abensour, 1987, p. 25) -, não se trata mais dos mesmos homens. A exemplo de Elena Valero, raptada, ainda menina, pelos Yanomami, com os quais conviveria até que, já adulta, optaria por evadir-se da tribo e brindar-nos com o relato dos anos vividos entre os indígenas, o que Clastres faz é uma etnografia selvagem: ao invés de permanecer apenas diante do mundo indígena, estará, também, dentro dele (Clastres, 1969b, p. 34). No lugar do pensamento selvagem, uma etnografia e uma política selvagens.

Como conseqüência, muda o herói do relato (Verdier in Abensour, 1987, p. 26). Os deuses batem em retirada (idem, p. 35) no próprio plano da narração: não há mais perspectiva das perspectivas, Sirius, o etnógrafo orgulhoso que retira a fórceps declarações de seus informantes. 
Gustavo B. Barbosa. A Socialidade contra o Estado...

Ainda que Clastres não busque absolutamente dissimular sua presença naquilo que relata (Dadoun in Clastres, 1972, p. 292) - discorrendo eventualmente inclusive em primeira pessoa (Lefort in Abensour, 1987, p. 184) -, quem verdadeiramente fala, age e reclama o centro da cena em sua etnografia são os Guayaki (Verdier in Abensour, 1987, p. 26), que, vivos, "ganham uma subjetividade geralmente excluída das análises antropológicas, [...] têm paixões, são ativos" (Goldman e Lima, 2001, p. 308). Clastres é um homem de campo (Abensour, 1987, p. 7) e querse cronista: nenhum resquício do desejo de construir um "sistema de explicação universal, ao qual todas as formações sociais passadas e presentes vêm revelar seus segredos" (idem, p. 44). "Não elaboro programas" - escreve -, "contento-me em descrever" (apud Cartry, 1978, p. 49). Às perguntas “o que isto significa?”, "como isto é possível?” ou "para que isto serve?", antepõe outra, menos ambiciosa: “como isto funciona?”. De fato, como propõe, “[o]s Aché são o que fazem” (Clastres, 1972, p. 209).

Atrás dos Aché, sua estratégia de investigação parece nomadizar (Deleuze in Clastres 1972, p. 297). Sempre em busca de linhas de conjunção, disjunção e fuga. A leitura de "O arco e o cesto" (1966), por exemplo, sugere uma primeira linha de conjunção: homens-caçadoresfloresta-arco-animais caçados. Tal linha chama outra, já de disjunção: mulheres-arco, uma vez que é interditado às mulheres tocar os arcos. Esta, por sua vez, induz outra linha, novamente de conjunção: mulheres-afazeres domésticos-acampamento-cesto. A partir daí, o texto inflaciona as linhas; eventualmente, porém, elas explodem numa linha de fuga. Especialmente se comparadas à relativa boa sorte de Krembegi, as desventuras de Chachubutawachugi, relatadas por Clastres em "Vida e morte de um pederasta" (1972), bem ilustram esse ponto. A perspectiva da linha de fuga - que viabiliza o abandono do "território" (Deleuze e Guattari, 1980, vol. 5, p. 224) - favorece certa riqueza analítica não apenas porque realça a "ordem" da sociedade em questão, mas porque poupa o estudioso 
Revista de Antropologia, São Paulo, USP, 2004, v. 47 no 2.

de estorvar seus informantes com apertadas camisas-de-força. Krembegi é um kyrypy-meno, um ânus-fazer-amor, um pederasta. Os Guayaki não lhe serão agressivos, desde que Krembegi não se pretenda um caçador, um homem. Entre os Guayaki, só se é homem contra a mulher, e Krembegi observará fielmente os limites daí decorrentes; portará um cesto, não um arco; e seus parceiros sexuais serão seus irmãos, em metáfora do incesto que confirma para o grupo que o incesto verdadeiro, entre irmão e irmã, ameaça o corpo social. "Krembegi é o mundo aché invertido, mas nem por isso é a contra-ordem da ordem social existente, [...] [ele constitui] imagem invertida, mas imagem, contudo, da ordem e das regras 'normais'" (Clastres, 1972, p. 219). Chachubutawachugi não desfrutará da mesma fortuna. Ainda que vítima de pane e, portanto, incapaz de caçar, quer permanecer no universo da masculinidade. Sua obstinação em ocupar um terceiro lugar, entre o masculino e o feminino, que, a rigor, não existe, suscitará resistência por parte dos Guayaki, que o consideram ridículo e, no máximo, passível de piedade. "[P]atético habitante de um impossível abrigo. Eis o que o torna 'invisível', ele está alhures, em parte alguma, por toda parte" (idem, p. 217) E, no entanto, Chachubutawachugi de fato existe, e esta sua existência - ainda que quase subliminar - encontra espaço nas páginas de Clastres.

Descrito assim de modo abstrato - adverte Deleuze (in Clastres, 1972, p. 297) -, este método de investigação que procede por linhas de conjunção, disjunção e fuga - perde muito de seu dinamismo e há o risco de que desapareça seu caráter progressivo. Desenvolve-se, por meio dessa composição em forma de irradiação, uma teoria local do grupo: pedaço por pedaço, segmento por segmento (idem). Não há necessidade de nenhuma totalidade preexistente - uma sociedade à Durkheim -, cujas partes seriam devidamente decupadas. Em vez de buscar estruturas, Clastres meramente acompanha o que os índios fazem e "[s]egue o caminho dos nômades selvagens" (idem). 
Gustavo B. Barbosa. A Socialidade contra o Estado...

Os incidentes da vida dos Guayaki terminam, assim, integrados num plano de intersubjetividade primeira, que pertence ao domínio sociológico e ao psicológico e a nenhum dos dois ao mesmo tempo, e que faz com que se empalideça até o ponto de seu total desaparecimento - as fronteiras entre as duas disciplinas. Escreve Clastres:

Preocupação constante dos índios em utilizar o acontecimento da história individual como meio de restaurar a unidade tribal, como pretexto para ressuscitar em cada um deles a certeza de constituir uma comunidade. [...] Dissimulam-se aí uma ética pessoal e uma filosofia da sociedade, segundo as quais é proclamado que o destino dos homens desenha sua figura somente sobre o horizonte do coletivo e exige de cada um a renúncia à solitude do seu eu, o sacrifício da delícia privada. (1972, p. 41)

"Ecos" da última página de As estruturas elementares do parentesco (LéviStrauss, 1967, p. 537)? Sem dúvida. Mas somente até determinado ponto.

De près et de loin. O diálogo que Clastres terá sabido manter com Lévi-Strauss jamais se traduziu em sujeição: sempre tão perto da problemática lévi-straussiana e, paradoxalmente, sempre tão longe. Alguns identificam nos afastamentos de Clastres com relação a Lévi-Strauss um eterno Durkheim à espreita. É bem verdade que o vocabulário mesmo utilizado por Clastres parece, em algumas ocasióes, reificar a sociedade, que beiraria o voluntarismo; é o que ocorre precisamente com seus artigos mais "populares", como "A sociedade contra o Estado" (1974b). A valorização excessiva do vocabulário possivelmente inadequado ou de raciocínios sinuosos de alguns de seus artigos, entretanto, apenas dificultará o acesso a chaves de leitura alternativas. $\mathrm{O}$ afastamento com relação a Lévi-Strauss não necessariamente implica um restabelecimento de Durkheim, até porque Clastres, no mais das vezes e particularmente 
Revista de Antropologia, São Paulo, USP, 2004, v. 47 no 2.

quando faz etnografia, evita as dicotomias simplificadoras do gênero indivíduo versus sociedade e não propõe nenhuma exterioridade entre as "máquinas sociais primitivas" e as "formas de subjetivação" que elas operam. No texto "O retorno das luzes", o próprio Clastres, ao rebater as críticas de Birnbaum, reflete sobre a distância que o separa de Durkheim:

Trata-se [...] [para Birnbaum] de estabelecer que "a sociedade contra o Estado se apresenta [...] como uma sociedade de constrangimento total". [...] O "controle social" exerce-se aí de maneira absoluta: não se trata mais da sociedade contra o Estado, é a sociedade contra o indivíduo. Ingenuamente, Birnbaum nos explica por que sabe tanto sobre a sociedade primitiva: leu Durkheim. (1977a, p. 149)

Conhece-se a dificuldade do estruturalismo em dar conta dos ritos (Clastres, 1978, p. 160). Esse "discurso magno da antropologia" (idem, p. 158) foi elaborado com outro objetivo: sua preocupação centra-se nos sistemas de parentesco e nos sistemas mitológicos. Tanto na análise do parentesco quanto na das mitologias, porém, o estruturalismo renuncia ao estudo do lugar de produção dos parentes e dos mitos: a sociedade (Abensour in Abensour, 1987, p. 9). "O que é eliminado, suprimido do discurso estruturalista, [...] é a sociedade concreta, seu modo de funcionamento, sua dinâmica interna, sua economia e sua política" (Clastres, 1978, p. 158). A “etnografia selvagem” de Clastres fará a diferença, e esta é mesmo a distinção fundamental entre Lévi-Strauss e Clastres: a preocupação de um é com a lógica que permite o funcionamento da sociedade, a do outro, com a lógica da sociedade em funcionamento. Lévi-Strauss, escreve Clastres, faz uma "teologia sem deus [...], uma sociologia sem sociedade" (idem, p. 160). Talvez seja esse mesmo o motivo por que Clastres tinha de utilizar a palavra sociedade, que não 
Gustavo B. Barbosa. A Socialidade contra o Estado...

trairá aí nenhum pendor durkheimiano. $\mathrm{O}$ que presenciaremos, em sua etnografia selvagem, serão sociedades-em-funcionamento, máquinas sociais em operação que, a partir das formas específicas de subjetivação que engendram e que as engendram, impedirão a emergência de exploradores e explorados, dominantes e dominados, agindo, portanto, contra a economia e contra o Estado.

O primeiro ensaio de Clastres - "Troca e poder: filosofia da chefia indígena” (1962) - lança programa de trabalho, ao qual ele permanecerá fiel ao longo de toda sua carreira, que parece inscrito em problemática tipicamente lévi-straussiana. Ao estudar o lugar da chefia nas sociedades primitivas, Clastres verificará que as "trocas" entre o chefe e o grupo se constituem dos mesmos elementos cuja circulação, de acordo com a teoria lévi-straussiana, instaura a sociedade - palavras, bens e mulheres -, o que estaria a indicar a natureza profunda das questóes colocadas pelo poder. Já aí, entretanto, Clastres não estatuirá nenhuma espécie de reciprocidade entre o chefe e o grupo: palavras e bens desenham fluxo de direção única, invariavelmente do chefe para o grupo; as mulheres tomam a direção inversa. Trata-se de "termos", portanto, que não se encaixam facilmente na categoria de "signos" que fundam a comunicação. Clastres espanta-se que o grupo reconheça a seu chefe - e recordemos que se trata de um chefe sem poder - o privilégio da poliginia. Por que, se não forçados a isto, os indígenas alienam ao chefe graciosamente um de seus bens mais valiosos, suas mulheres? $\mathrm{O}$ impasse revela aspecto fundamental da política, presente mesmo no "poder não potente" dos chefes indígenas: o poder é contra o grupo. O chefe beneficia-se de mulheres a mais, e as palavras e os bens que caminham na direção contrária são insuficientes para qualquer espécie de compensação. O artigo "A economia primitiva" (1976c) traz esclarecimentos suplementares. A unidade familiar do chefe, fortalecida com os "braços extras" de suas "mulheres extras", terá como produzir os bens que o grupo espera 
receber dele: isto porque o chefe deve ao grupo. Deve palavras - daí a importância de seu manejo da oratória (e os discursos, sempre ignorados, imporão ao chefe a evidência de que não dispõe de voz de comando) -; deve bens - daí sua "generosidade forçada". Mais ainda: a dívida demonstra onde, verdadeiramente, está o poder nas sociedades primitivas: no grupo, que submeterá o chefe à condição de seu eterno devedor (idem, p. 140).

No lugar da reciprocidade, a dívida. No lugar da troca, a guerra. Diferenças com Lévi-Strauss - e, definitivamente, diferenças que fazem diferença. A "revolução copernicana” a que Clastres nos convida, em "Copérnico e os selvagens" (1969a), exige que pensemos "dívida" e "guerra" em sua positividade e não como reflexos da falta - de fé, leis e reis - que condenariam as sociedades primitivas a um estádio aquém do político. A dívida evidencia o lugar do político nos grupos indígenas, ao produzir, num só movimento, um chefe sem poder e uma sociedade sem Estado, sem corpo político que paire acima dela, portanto. Será o mesmo fito que perseguirão a máquina produtiva e a máquina de guerra dos primitivos, ambas resguardando a totalidade una das sociedades primitivas, isto é, mantendo-as como todo homogêneo e evitando a emergência do Um, do Estado, da distinção entre um chefe-que-ordena e um grupo-que-obedece (Clastres, 1977b, p. 191-2).

A máquina produtiva primitiva persegue um ideal de autarquia, porque opera segundo uma lógica do centrífugo, exatamente como a máquina de guerra (idem, p. 194-5). Opondo os grupos, os conflitos armados conspiram contra sua unificação e permitem a cada um manter a sua totalidade una contra o princípio unificador do Um, o Estado: as sociedades primitivas exigem uma leitura de Hobbes às avessas. Por esse motivo, a sociedade contra o Estado é uma sociedade-para-a-guerra (idem, p. 187 e 201). Reside aí precisamente sua positividade, que impedirá a Clastres de proceder a uma leitura troquista da guerra e 
Gustavo B. Barbosa. A Socialidade contra o Estado...

caracterizá-la, a reboque de Lévi-Strauss, como simples negação da troca, como a troca que não deu certo (idem, p. 186 et passim). Novamente, a negação da reciprocidade; novamente, a releitura e ampliação da problemática de Lévi-Strauss. Clastres não questiona que, no nível de uma socio-lógica, da preocupação de inspiração kantiana com as condiçôes de possibilidade da vida social, a reciprocidade operará e garantirá a instituição da sociedade, por meio do estabelecimento de uma descontinuidade com relação à natureza (idem, p. 198). Isso não nos faculta, porém, procurar troca e reciprocidade partout, como se cada piscadela de olho tivesse de ser devolvida. Daí a necessidade de distinção dos planos em que a análise é desenvolvida (idem, p. 188 e 199 et passim) no da instituição da sociedade, a troca necessariamente agirá; no da vida social em funcionamento, não, precisamente conforme ilustra a discussão a respeito da troca de mulheres e da aliança com os cunhados. A proibição do incesto obriga à troca de mulheres: neste sentido, funda a sociedade e inaugura a distinção, a nossa separação definitiva da animalidade. Até aí, Clastres acompanha Lévi-Strauss (idem, p. 201). Mas a operacionalização da troca de mulheres, a troca de fato, em operação, exige outro tipo de raciocínio: neste terreno, estabelece Clastres, a guerra precederá à aliança, e a aliança estabelecerá os limites da troca. É porque as sociedades primitivas têm inimigos - e precisam tê-los, se não os tivessem teriam optado por inventá-los (idem, p. 204), na medida em que as guerras conspiram a favor da lógica do centrífugo - que os cunhados são necessários. Espera-se, portanto, que as alianças fortaleçam o grupo, habilitando-o a defender-se e a preservar sua autonomia e independência diante dos demais.

Clastres parece perguntar-se: como, a partir de Lévi-Strauss, se pode fazer etnografia? Será o próprio Lévi-Strauss, entretanto, que sairá transformado do embate com a etnografia selvagem. A sociedade que retorna à cena com Clastres não mais padece, porém, das mesmas moléstias que, 
Revista de Antropologia, São Paulo, USP, 2004, v. 47 no 2.

desde Durkheim, comprometem irremediavelmente o conceito. Não se trata aí de entidades coesas, unidades discretas, a se oporem, em pretensa concretude, à sua inescapável (e politicamente perigosa) excrescência, o indivíduo 7 .

A obra de Clastres - etnográfica, em sua essência - termina por comportar inapelavelmente uma dimensão filosófica e política (Abensour, 1987, p. 7). Em certo sentido, o conhecimento etnológico intima a interrogação filosófica, na medida mesma em que a vida social implica, para os que nela se encontram imersos, um questionamento sobre o homem e o mundo (Lefort in Abensour, 1987, p. 191-2). Etnólogo e filósofo - e os dois ao mesmo tempo -, Clastres levará sua reflexão sobre as sociedades primitivas suficientemente longe de forma a "revelar-nos um aspecto desconhecido e crucial de toda sociedade" (Gauchet, 1977, p. 55). Evitará, dessa maneira, os essencialismos e os teleologismos - sejam os da sociedade, sejam os do Estado - e nos legará obra que, filosófica e etnológica a um só tempo, ganhará forma ao encontro de um planeta sociológico diferente do nosso (Richir in Abensour, 1987, p. 61-2).

\section{Radículas: o "Estado" em Clastres e a filosofia política}

Clastres jamais fez ciência de Estado. Não exatamente no sentido de que não tenha constituído uma sociologia política. Ainda que não tenha propriamente instituído uma escola - Clastres "pertence a uma família de espíritos sem espírito de família” (Meunier in Clastres, 1972, p. 307) -, fundou, sim, uma sociologia política, só que de outro modo e a partir de outra perspectiva. Trata-se aí do sentido mesmo da revolução copernicana por ele proposta (1969a, p. 23), ao proceder ao deslocamento da privação para a oposição e identificar, nas sociedades indígenas, não ausências - de fé, leis e reis - mas presenças e vontades afirmativas - 
Gustavo B. Barbosa. A Socialidade contra o Estado...

contra a economia e o Estado. A asserção acerca do estatuto plenamente político das sociedades indígenas assenta-se numa aposta: a de que é possível escapar ao guarda-chuva do Estado e pensar fora das fronteiras por ele impostas, o que, no limite, culminará com o questionamento da própria instituição como princípio inescapável de organização social.

Tanto a chamada antropologia política quanto a filosofia política viciaram-se muito cedo no ponto de vista do Estado e tenderam a conduzir a atenção para a análise da ordem, da coesão e das instâncias de controle. Entretanto, tal privilégio denuncia precisamente certa consagração da perspectiva do Estado, como se se aceitasse como "necessidade antecipadamente dada aquilo que talvez só exista como seu modo próprio de operação" (Goldman e Lima, 2001, p. 304). O círculo, dessa maneira, fecha-se em discutível filosofia da história, à qual Clastres confronta uma etnologia que nos exclui nem tanto como objetos mas como pontos de vista.

Apesar de a tradição das gerações mortas pesar como pesadelo sobre o espírito das novas, muito cedo os trópicos imporiam suas particularidades aos antropólogos que aqui desembarcaram a partir da década de 1960. O instrumental analítico de inspiração fortesiana que muitos traziam em sua bagagem logo revelaria suas insuficiências. "As tipologias britânicas das sociedades africanas são possivelmente pertinentes para o continente negro; não servem de modelo para a América", antecipa Clastres (1969a, p. 12). Salvo no caso de raras exceçôes, a equação tradicional que reduz o poder à coerção e à relação comando-obediência precisamente nossa concepção do que deva ser a política - não funciona na América (idem, p. 10 e 11), e, por detrás da recusa da etnologia em reconhecer o caráter eminentemente político do poder não-potente característico das sociedades ameríndias, esconde-se, em eterna espreita, o "adversário sempre vivaz" (idem, p. 15) da pesquisa antropológica, o etnocentrismo, que, ao fazer de nós mesmos inescapáveis telos de todos 
Revista de Antropologia, São Paulo, USP, 2004, v. 47 no 2.

os grupamentos humanos (Clastres, 1974a, p. 161), "mediatiza todo olhar sobre as diferenças para identificá-las e finalmente aboli-las" (Clastres, 1969a, p. 15). Se as sociedades indígenas rejeitam o poder político como coerção ou violência, tal negação não necessariamente traduz um vazio. "Algo existe na ausência" (idem, p. 21), assegura Clastres. Pode-se pensar o político sem a violência, mas não há como pensar o social sem o político (idem, p. 21).

Lebrun recorda que a definição de política costuma fazer-se acompanhar da noção de força (1984, p. 11). Recorre, sobre o particular, a enunciado de Julien Freund sobre a política: "[Trata-se d]a atividade social que se propóe a garantir pela força, fundada geralmente no direito, a segurança externa e a concórdia interna de uma unidade política particular" (idem, p. 11). O poder - que pressupõe a força de acordo com tal visão - só existiria assim contra alguém: só haveria dirigentes, capatazes, caudilhos, timoneiros e presidentes porque os destituídos de voz de comando acatariam suas ordens (idem, p. 18). Pouco importa que o poder - e, já a esta altura, qualifiquemo-lo oportunamente como potente - se tenha burocratizado, tecnicizado, sofisticado, de forma a organizar a dominação: seu fundamento, a força, continuaria indistinto (idem, p. 22). Nem sempre é assim. Nem sempre foi assim.

Por conta de sua opção pela etnologia, a aparente renúncia de Clastres à filosofia política naturalmente não vai desobrigá-lo de a ela retornar eternamente (Cartry, 1978, p. 47-8; Abensour in Abensour, 1987, p. 115-6). Como algo continua a funcionar mesmo na aparente renúncia, a filosofia política, inicialmente desterritorializada pela démarche de Clastres para ser reterritorializada logo a seguir, revelará potencialidades até então insuspeitas. Loraux inicia-nos em salutar "despudor acadêmico" ao confessar o prazer com que desrespeitou a interdição - recomendada pela moral e pelos apelos ao método - da comparação (in Abensour, 1987, p. 157). Especialistas em Grécia clássica, garante ela, sentem-se, 
Gustavo B. Barbosa. A Socialidade contra o Estado...

no mais das vezes, em casa e encontram, ao menos até determinado ponto, cumplicidade entre os Guayaki de Clastres ${ }^{8}$ (idem, p. 155). Uma sociedade indivisa que, desejando permanecer como tal, recorre à guerra - como mecanismo que produz e protege a dispersão dos diferentes grupos - para preservar-se perante a multiplicidade de outras unidades de natureza semelhante: "Clastres fala dos índios; eu penso nos gregos", escreve Loraux (idem). A mesma regra prevalece num caso e no outro: contra o exterior, a violência, de forma a eliminar as distensôes entre os companheiros indígenas e entre os cidadãos gregos (idem). Tanto entre os Guayaki quanto entre os atenienses, portanto, a indivisão interna não é dada nem imediata: sua manutenção e reinstauração exigem estratégias específicas (idem, p. 157).

Também para Lebrun, a arkhé politiké dos gregos em nada antecipa o conceito de poder político da modernidade, visceralmente dependente da idéia de dominação (1984, p. 26). O expositor, por excelência, de tal conceito será, ainda por excelência, um antiaristotélico (idem, p. 37): Thomas Hobbes. Os requisitos da política à Hobbes subverterão a teleologia aristotélica. Os cidadãos - antes iguais pelo mito grego da autoctonia (idem, p. 43) - terão sua igualdade preservada, só que em sua submissão diante de outro mito, o Leviatã (idem, p. 44). A comunidade por princípio, à la grega, não existe mais, e a integração dos homens - retraídos em seu atomismo de lobos desagregados, ciosos de sua independência e egoístas na defesa de seus interesses - somente ocorre por meio da operacionalização do Leviatã, mediante a criação dos estratagemas adequados: o indivíduo, isolado, apolítico e detentor de direitos naturais (idem, p. 44 e 45); o povo, constituído como corpo político (idem, p. 32-3) e, finalmente, a sociedade (societas), como esfera em que se desenvolve a vida privada, distinta da participação na vida pública (idem, p. 37). É inextricável, portanto, o laço estabelecido entre o advento do indivíduo isolado, entendido como ferramenta fundamental na 
Revista de Antropologia, São Paulo, USP, 2004, v. 47 no 2.

construção da política, e a instituição do poder único como condição da Cidade (civitas). A diferença entre civitas e societas cavará o abismo, o gap abissal, a moderna fantasmagoria que sepultará definitivamente para nós a Grécia, na qual o homem só realizava a sua essência de animal político pela participação plena nos negócios da polis (Châtelet, Duhamel e Pisier-Kouchner, 1982, p. 15). Ao transferir o direito de governar-se a si mesmo ao Leviatã, identificado como a única antidesordem eficaz possível (Lebrun, 1984, p. 35), o cidadão moderno - já agora inapelavelmente súdito - inaugura a cisão vida privada/negócios públicos, sociedade (societas)/civitas. A vida em sociedade não mais requer a vida na Cidade; irremediavelmente despolitizado, o homem - já um "indivíduo”... - passará a ocupar-se dos assuntos que apenas lhe dizem direito, transferindo a condução dos negócios públicos ao Leviatã. O Estado, portanto, não só viabiliza, como, em certo sentido, inventa tanto a sociedade quanto o indivíduo (idem, p. 38 e 45). Como operação, o Estado exige, assim, para funcionar, o concurso de figuras subjetivas e ordenamentos sociais específicos - o "indivíduo" e a "sociedade". Resta saber o que ocorre com tais figuras e ordenamentos quando sai de cena ou, ao menos, deixa de prevalecer a operação Estado.

Étienne de La Boétie promove um deslizamento da História para a lógica (Clastres, 1976b, p. 112) e espanta-se que tantos tenham se sujeitado a só um e que o tenham feito de bom grado: "[Q]ue malencontro foi este que tanto desnaturou o homem, o único nascido, de verdade, para viver livremente (...)?” (La Boétie, 1576, p. 143). O assombro devese ao fato de que, ainda que as sociedades a que se refere La Boétie lhe fornecessem apenas exemplos do malencontro, ao menos no terreno da lógica poderia imaginar-se que tudo pudesse processar-se de outro modo. Clastres proporá outro deslizamento, da lógica de volta para a história o que, por ironia, demonstrará que o Estado não é historicamente inelutável (Clastres, 1976b, p. 112; Châtelet e Pisier-Kouchner, 1983, p. 712). 
Gustavo B. Barbosa. A Socialidade contra o Estado...

Seu espanto diferencia-se do de La Boétie. Ele pergunta-se: por que Jyvukugi, o "chefe" dos Guayaki em Arroyo Moroti, obrigava-se a ir de tapy em tapy notificar seu povo daquilo de que todos já tinham conhecimento, porque previamente informados pelo paraguaio que se encontrava à frente do acampamento?

Pela primeira vez, eu podia observar diretamente - pois ela funcionava, transparente, sob meus olhos - a instituição política dos índios. [...] Os Guayaki, votados à [...] filosofia política selvagem, separavam radicalmente o poder e a violência: para provar que era digno de ser chefe, Jyvukugi devia demonstrar que, diferente do paraguaio, ele não exercia sua autoridade por meio da coerção, mas que, ao contrário, a desdobrava no que é mais oposto à violência, [...] na palavra. (Clastres, 1972, p. 78-9)

Presenciamos aí, sob nossos olhos, um não-Estado em operação, que confere nova inteligibilidade ao Estado, também em operação, e já entre nós (e não apenas). Ensina Clastres: o Estado não é "os ministérios, o Eliseu, a Casa Branca, o Kremlin. [...] O Estado é o exercício do poder político" (1978, p. 166; grifo meu). Diante de um poder que se exerce, a pergunta "como isto funciona?" é mais profícua do que as alternativas, e muito mais ambiciosas, "o que isto significa?" ou "de onde isto vem?". Isso funciona pela concorrência de máquinas sociais e figuras subjetivas específicas, que fazem isso funcionar. $\mathrm{O}$ mesmo vale para um poder que não se exerce.

O poder que não se exerce, o não-Estado opera por meio de máquinas sociais e figuras subjetivas que conjuram diuturnamente a possibilidade da emergência da divisão no seio do grupo. As sociedades contra o Estado recorrem a estratégias próprias e lançam mão de vigorosos mecanismos - como a guerra, a economia, a religião, a linguagem e a própria "subjetivação" de seus "chefes - de forma a evitar que surjam nelas o 
Revista de Antropologia, São Paulo, USP, 2004, v. 47 no 2.

mau desejo de comandar e, como sua necessária contrapartida, o de obedecer (1976b, p. 119). E vemos, assim, o quanto há de político no desejo (1977a, p. 154-5).

Hobbes e os selvagens. Desse embate, surge o "Contra-Hobbes" de Clastres (Abensour in Abensour, 1987, p. 121): sói pensar a guerra de outra forma. Não mais como sintoma de estado associal (ou, pior, présocial, em raciocínio que de novo nos eleva a telos inescapável dos grupos indígenas) e de caos inclemente, mas como mecanismo mesmo de instituição do cosmos social primitivo (Clastres, 1977b, p. 195). A guerra, como máquina anti-Estado por excelência, preserva a lógica do múltiplo, característica dos grupos indígenas, e conspira contra o Um (idem, p. 188): há uma socialidade que se institui na e pela guerra, o que nos obriga ao saudável exercício intelectual de, por um lado, evitar os maniqueísmos dialeticamente excludentes e, por outro, pensar guerra $e$ sociedade e a um só tempo. Para Clastres, a politeia selvagem, forma original da política, institui-se na e pela guerra, não porque a guerra atraia a troca e clame o nascimento da razão, mas porque, na e pela guerra, passamos de "lobos a homens" (Abensour in Abensour, 1987, p. 128). A comunidade primitiva inscreve sua ordem política num território de onde se exclui violentamente o Outro (Clastres, 1977b, p. 189 e 192), e isto demarca sua política externa; sua política interna conspirará para sua afirmação como unidade homogênea, impedindo a emergência de qualquer clivagem em seu seio, de qualquer divisão entre dominantes e dominados.

Como se faz um chefe? Com suas palavras - e também com o suor de seu próprio rosto. E o de suas mulheres, que a poliginia estrategicamente lhe concede (Clastres, 1962, p. 33; 1976c, p. 137-8; Lizot, 1976, p. 167). Os três termos - palavras, bens e mulheres -, cuja troca havianos garantido a travessia definitiva da animalidade para a sociedade, servem-se agora a torções (Clastres, 1962, p. 34 et passim) -, e não no 
Gustavo B. Barbosa. A Socialidade contra o Estado...

terreno etéreo das mitologias, mas sob nossos olhos, assegurando-nos a passagem, também ela irrevogável, da sociedade para a socialidade política. Não porque exista aí já um déspota em miniatura (Clastres, 1972, p. $81 ; 1974$ a, p. 175), cujas potencialidades as formas posteriores de organização política desdobrariam de maneira cada vez mais perfeita. Mas porque o problema da política se coloca aí já em sua inteireza - o poder é inevitavelmente exterior e contra o grupo (Clastres, 1962, p. 38; Gauchet, 1977, p. 64) - e resolve-se, com particular sutileza (Clastres, 1962, p. 40), por meio do estabelecimento de uma instituição - a chefia - que funciona no vazio e, justamente por esta razão, funciona. Funciona negando e indo contra a exterioridade do poder: ao fazer com que se rompa, precisamente no lugar da chefia, a lógica da reciprocidade, a sociedade primitiva, ao mesmo tempo em que reconhece a exterioridade inescapável que qualifica o poder, inibe suas virtuais ameaças, impedindo que o líder se decalque como um núcleo pesado que paire sobre os demais membros da comunidade (Clastres, 1962, p. 38; Richir in Abensour, 1987, p. 63). Na verdade, o chefe passa a dever ao grupo e permanecerá na chefia enquanto persistir na dívida (Clastres, 1976c, p. 141): sua "generosidade" constitui mais do que uma obrigação: uma eterna - e voluntária? - servidão (Clastres, 1962, p. 28).

Impede-se, desse modo, que se torne predominante um poder que já está lá, presente na aparente ausência.

[As sociedades primitivas] não eliminam pura e simplesmente delas a dimensão do poder [escreve Gauchet]. Não fazem como se o poder não existisse. Ao contrário, colocam um "chefe", um indivíduo formalmente distinto dos demais, no lugar que poderia ser aquele de alguém que dá ordens, enuncia regras, detém a força. [...] [C]olocam-no lá para marcar [...] que o lugar permanece vazio. (1977, p. 59-60) 
Conjurar é preceder (Deleuze e Guattari, 1980, vol. 5, p. 121) e, se as sociedades primitivas rejeitam o Estado, é porque ele já está lá (Gauchet, 1977, p. 60): "sim" - concede Clastres - "o Estado existe nas sociedades primitivas" (in Carrilho, 1976, p. 76). De fato, quanto mais os arqueólogos escavam, mais descobrem Estado (Deleuze e Guattari, 1980, vol. 5, p. 23).

A presença diuturnamente conjurada do Estado nas sociedades primitivas - além de emprestar inteligibilidade ao funcionamento da politeia selvagem, aos mecanismos sociais primitivos e às figuras subjetivas específicas, por meio das quais ela opera - permite-nos ver o nãoEstado onde ele aparentemente não está e, ainda assim, atua: entre nós. Viabiliza-se, dessa maneira, uma antropologia que se entende como diálogo, como ponte - e de via dupla - lançada entre nossas sociedades e aquelas de "antes da partilha" (Clastres, 1968b, p. 37). Exposta a absoluta vulnerabilidade dos dualismos ontológicos excludentes - que obrigam a que as sociedades ou tenham Estado ou não o tenham, que sua política ou se defina como segmentária ou como centralizada, que sejamos ou homens ou jaguares, e que os Bororo sejam ou Bororo ou araras; descartadas apriorística e prematuramente as férteis possibilidades de misturas e justaposiçôes -, novos horizontes descortinam-se para a análise, em indicação de que "fecundantes corrupções" podem - desde que pensemos contra a corrente - revelar potencialidades até então insuspeitas em "idiomas" antes tomados no radical isolamento de seu monadismo. Escrevem Deleuze e Guattari:

Existem já nas sociedades primitivas tantos centros de poder quanto nas sociedades com Estado; ou, se preferimos, existem ainda nas sociedades com Estado tantos centros de poder quanto nas primitivas. (1980, vol. 3, p. 87; grifo dos autores) 
Gustavo B. Barbosa. A Socialidade contra o Estado...

Há, assim, um certo estado de Estado, constante e presente por toda parte, e um certo estado de guerra, também ele constante e presente por toda parte, um ou outro, inibidos ou potencializados, a depender da forma como se dá a operação dos mecanismos sociais e das figuras subjetivas por meio dos quais atuam. Num e noutro estados, entretanto, algo sempre ficará de fora, reclamando e impondo presença apesar da ausência aparente. São mesmo insolentes os tais moleques de Bogotá (Meunier, 1977)9.

\section{Rizomas: o "contra" em Clastres e a antropologia menor}

Algumas anedotas devem ser levadas a sério. Ao tentar desqualificar os argumentos de Marilyn Strathern e Christina Toren, suas opositoras num debate sobre a obsolescência teórica da concepção de sociedade, no qual ambas advogavam sua substituição pela de socialidade, Jonathan Spencer vale-se da ironia: “A Socialidade contra o Estado', de alguma forma, perde a força do título original de Clastres" (in Ingold, 1996, p. 80). Será mesmo assim?

$\mathrm{Na}$ realidade, em duas oportunidades, o próprio Clastres utiliza o termo "socialidade" 10 . Ainda que, no que se refere à relação entre os dois autores, as idéias de prenúncio e de precedência sejam, no mínimo, complicadas (e se conjurar é preceder, talvez preceder seja também conjurar), e que não queiramos ver em Clastres, de modo algum, uma Strathern (1988) em forma embrionária ou fetal - démarche ademais totalmente descabida -, o emprego da palavra "socialidade" nestas duas oportunidades deveria, ao menos, instigar-nos à curiosidade ${ }^{11}$.

De fato, acabamos de verificar como Clastres promove certa dessubstancialização do Estado, que não é "o Eliseu, a Casa Branca, o Kremlin" (1978, p. 166), mas um "acionamento efetivo da relação de poder" 
Revista de Antropologia, São Paulo, USP, 2004, v. 47 no 2.

(1976b, p. 115). Evidentemente, ele procederá da mesma maneira com o anti-Estado e com a "sociedade" (por assim dizer), ambos também vistos como acionamentos efetivos de relações, como máquinas que funcionam - "isso trabalha” -, e funcionam precisamente por meio das figuras subjetivas que produzem e que as põem em operação: os chefes, eternamente imersos na dívida; os guerreiros, em eterna busca por guerras que lhes confiram prestígio; os maridos, eternamente constrangidos a compartilhar as respectivas mulheres com outros consortes; os caçadores, eternamente obrigados a doar as presas que estão proibidos de consumir; os homens e as mulheres, cujos corpos - eternamente marcados pelos rituais de iniciação - lhes rendem a evidência da eterna lei do grupo - "vocês, cujas peles trazem as idênticas marcas, não valem mais do que os outros". Não se deve imaginar, entretanto, que tais figuras sejam erguidas à condição de tipos ideais e enlevadas ao imaterial céu teórico, do qual contemplariam, abstratas, nossa demasiada humanidade. Têm nomes, estão vivas, têm paixões e reaçôes de viventes (Goldman e Lima, 2001, p. 308).

Tampouco existem aí propriamente indivíduos. O “contra" em Clastres - que, rizomaticamente distribuído em sua obra, lhe assalta constantemente os eventuais núcleos de dureza - jamais lhe autorizou estatuir a existência de um "indivíduo" contra a "sociedade". Ao estabelecer a fórmula "a sociedade contra o Estado" - que, mais propriamente, queremos crer, deveria ser "a socialidade contra o Estado" -, Clastres raciocina não em termos de entidades abstratas - " $a$ sociedade”, " $o$ Estado" -, mas, tanto de um lado quanto de outro, no sentido de máquinas sociais sem nenhuma externalidade com as formas de subjetivação que engendram e por meio das quais operam. Presencia-se, em alguns dos ensaios de Arqueologia da violência (1980b) e especialmente em sua etnografia sobre os Guayaki (1972), o funcionamento de máquinas sociais produzindo chefes, guerreiros, homens, mulheres, homossexuais, 
Gustavo B. Barbosa. A Socialidade contra o Estado...

nem-homens-nem-mulheres-nem-homossexuais, por meio dos quais aquelas máquinas operarão.

Etnograficamente - pois "isso trabalha" 12 -, Clastres enfrenta algumas das dificuldades com que se depara a antropologia. Com efeito, em nome de entidades metafísicas - como o "indivíduo" e a "sociedade", que, apesar de "falácias da concretude deslocada", parecem gozar de existência supostamente material -, costuma-se obliterar, com freqüência, aquilo que é verdadeiramente constitutivo: as relações. $\mathrm{O}$ desafio é precisamente este: ao tentar sair do individualismo metodológico sem cair em certo holismo transcendental ou vice-versa, como pensar a relação social mesmo na ausência de sociedade ou, se se preferir, como construir modelos de intencionalidade sem sujeitos?

Em sua obra, Clastres multiplica - em "progressão rizomática", por assim dizer - os exemplos etnográficos de como a "objetividade" da socialidade pode operar por meio da "subjetividade" das pessoas-eminteração. "Notemos [...] que a interrogação do autor é dupla" - observam Goldman e Lima.

Trata-se, por um lado, da sociedade enquanto máquina e, por outro, daquilo que faz a máquina funcionar concretamente e consiste, ao mesmo tempo, em efeito de sua existência e condição de seu funcionamento. [...] Pois, como Clastres a encara [a idéia da "sociedade contra o Estado"], ora como propriedade das máquinas sociais primitivas, ora sob o ângulo das figuras subjetivas que as acompanham, corremos o risco de perder de vista que estamos nos dois casos diante da mesma coisa. (2001, p. 306-8)

Já sabemos como um chefe se faz: pelo suor de seu próprio rosto, o que, pela "generosidade" a que se vê forçado, lhe permite saldar para com o grupo, e nunca por completo, sua eterna dívida, necessariamente uma relação. Ele permanecerá na chefia na medida em que for capaz de 
perseverar na dívida. Nenhuma externalidade, pois, separa o chefe de seu grupo: a dívida põe a ambos em relação e define-lhes os respectivos lugares. Enquanto se alimenta no chefe certo desejo de prestígio - cuidando-se, evidentemente, de saciá-lo -, proíbe-se-lhe, num só tempo, o acesso a certo desejo de poder, devidamente repreendido (Clastres, 1976c, p. 139). Tanto o chefe quanto seus "liderados" terminam satisfeitos, só que em seu bom desejo:

Em troca de sua generosidade, o que o big-man obtém? Não a realização de seu desejo de poder, mas a frágil satisfação de seu ponto de honra, não a capacidade de comandar, mas o inocente gozo de uma glória cuja manutenção o esgota. Ele trabalha em sentido próprio para a glória. A sociedade a concede de bom grado, visto que está ocupada em saborear os frutos da labuta de seu chefe. Todo bajulador vive às custas daquele que o escuta. (idem, p. 139)

Por essa prática, realiza-se uma intenção que é propriamente política, e política já em sua inteireza. Todas as análises de Clastres concorrerão para esse ponto, sempre em busca das máquinas sociais e das figuras subjetivas que boicotarão cotidianamente eventuais veleidades hierárquicas. "Sua tese geral se fundava sobre análises convergentes" - concorda Lefort, para enumerá-las a seguir:

[A] da chefia que revela a interdição feita àquele que foi instalado numa posição preeminente de exercer o comando; a do ritual de iniciação, no qual os velhos imprimem sobre os corpos dos adolescentes, por meios que se assemelham aparentemente à tortura, a lei da comunidade - uma lei da qual eles saberão para sempre que ela impõe a cada um permanecer igual aos demais; [...] ou a das guerras incessantes às quais se dedicam as tribos selvagens, cuja função parece ser a de manter a integridade de cada uma 
Gustavo B. Barbosa. A Socialidade contra o Estado...

em função da luta contra o estrangeiro ou, de forma mais geral, a de preservar a configuração de um mundo diversificado, rebelde a qualquer intrusão de uma potência conciliadora e unificadora. Os fatos que vários etnólogos haviam já descrito sem relacioná-los uns aos outros, Clastres os reúne e esclarece, demonstrando, por cima da singularidade dos comportamentos e das instituições, uma intenção comum a todas as sociedades primitivas, uma intenção política. (in Abensour, 1987, p. 190)

De fato, a mesma "ordem preside a disposição das linhas de força desta geografia" (Clastres, 1972, p. 212): seja na forma como um guerreiro se faz; como um caçador se faz; como um marido se faz; e, finalmente, como homens e mulheres adultos se fazem ${ }^{13}$.

Como se faz um guerreiro? Pelo seu próprio sangue, que, se não em situação de guerra em face de outros guerreiros, jorrará, no entanto, em vão. Com efeito, do mesmo modo que não há guerra sem guerreiros, não haverá guerreiros sem guerras: "o guerreiro é antes de tudo sua paixão pela guerra” (Clastres, 1977c, p. 219). Os guerreiros fazem-se na e pela guerra - cujo estado permanente preserva a lógica do centrífugo das sociedades indígenas, mesmo que as batalhas de fato não sejam constantes - e nas e pelas relações com os outros guerreiros. O desejo de prestígio do guerreiro, perseguido individualisticamente em competição consigo mesmo e com os demais, vai levá-lo a aspirar, no limite, à morte gloriosa. Impede-se, assim, e no mesmo golpe, que, por um lado, o grupo dos guerreiros - atravessado sempre por discórdias intestinas, porque a glória de cada um só se faz às custas de e em comparação com a dos demais - se afirme como facção que alimente o capricho de subordinar a sociedade, e, por outro, que um guerreiro, eventualmente mais valente, queira tornar-se chefe e tome para si o comando: a esta altura, ele já estará inapelavelmente morto (Clastres, 1974a, p. 178-9). Tragado por uma inescapável "escalada da temeridade" (Clastres, 1977c, 
Revista de Antropologia, São Paulo, USP, 2004, v. 47 no 2.

p. 233), "ajustamento exato entre o mundo ético dos valores tribais e o ponto de honra individual do guerreiro" (idem, p. 217), nosso duelista apenas levará a cabo sua sorte: submetendo-o a uma eterna "fuga para adiante" (idem, p. 229) - cada conquista, se serve para nutrir seu prestígio, coloca-o à prova e constrange-o a outras façanhas, ainda mais audaciosas -, sua constante insatisfação condena-o de antemão. Clastres relata-nos o infortúnio dos guerreiros selvagens: "[O] guerreiro não é jamais um guerreiro, a não ser no infinito de sua tarefa, quando, realizando a proeza suprema, ganha a morte, juntamente com a glória absoluta” (idem, p. 237; grifos do autor).

Expressōes como "desejo" e "vontade", em Clastres, não traem nenhuma inspiração psicologizante, como se eterno espectro do "indivíduo" estivesse a perseguir-nos. Tais expressões "não remetem a constantes enraizadas em uma pretensa natureza humana dada de antemão, mas sim aos efeitos subjetivos de determinados funcionamentos que se dão sobre um plano de intersubjetividade primeira e que se manifestam igualmente no nível sociológico propriamente dito" - ensinam Goldman e Lima (2001, p. 308). No que fazem eco a Deleuze: "Quanto à etnografia, Clastres disse tudo, em qualquer caso o melhor para nós. O que tentamos é pôr a libido em relação com um 'exterior'” (in Carrilho, 1976, p. 80).

A leitura desta parte deste artigo deve ser sumariamente descartada se tiver se prestado à cristalização de noções identitárias estanques, do gênero $o$ chefe, $o$ guerreiro etc. Nenhuma necessidade aqui das máquinas identitárias, de produção de rostidade, elas próprias já e inescapavelmente uma forma-Estado de pensar. De fato, "o rosto é uma política” (Deleuze e Guattari, 1980, vol. 3, p. 50) e existem agenciamentos de poder que prescindem do rosto (idem, p. 42). Nas sociedades primitivas, muito pouco passa pelo rosto, pois "os 'primitivos' podem ter as cabeças mais humanas, as mais belas e mais espirituais; eles não têm rosto 
Gustavo B. Barbosa. A Socialidade contra o Estado...

e não precisam dele" (idem, p. 43). E Deleuze e Guattari indicam a razão para isto: "O rosto não é um universal, nem mesmo o do homem branco; é o próprio Homem branco (...). O rosto é o europeu típico" (idem, p. 43), cuja unidade é constituída pela opção entre escolhas sempre excludentes: é um homem ou uma mulher; um rico ou um pobre; um adulto ou uma criança; um chefe ou um subalterno; um x ou um y (idem, p. 44). As máquinas polívocas primitivas descortinam novas possibilidades - e também para nós. Quando se atenta para que as pessoas serão múltiplas em função mesmo das relações intersubjetivas variadas de que, num só tempo, estarão participando e constituindo, compreende-se que possamos ser e à la fois crisântemos e espadas, cidadãos da Inglaterra, maridos, pais, pedreiros, membros de uma certa paróquia, votantes de um certo círculo eleitoral, membros de um sindicato, filiados ao Partido Trabalhista, homem e mulher: "nossos mil pequenos-sexos" (idem, p. 91).

Há, com efeito, uma outra forma de individuação que dispensa os sujeitos e os indivíduos, e que Deleuze e Guatari chamam de hecceidades:

Uma estação, um inverno, um verão, uma hora, uma data têm uma individualidade perfeita, à qual não falta nada, embora ela não se confunda com a individualidade de uma coisa ou de um sujeito. São hecceidades, no sentido de que tudo aí é relação de movimento ou de repouso entre moléculas ou partículas, poder de afetar e ser afetado. [...] É o próprio lobo, ou o cavalo, ou a criança que param de ser sujeitos para se tornarem acontecimentos em agenciamentos que não se separam de uma hora, de uma estação, de uma atmosfera, de um ar, de uma vida. (idem, vol. 4, p. 47 e 50)

Verdadeiros fatos sociais totais - e não apenas e muito mais.

Portanto: nem "todo", nem "partes". Ultrapassado certo fetichismo metodológico que a antropologia terá sempre mostrado pelo todo e ven- 
Revista de Antropologia, São Paulo, USP, 2004, v. 47 no 2.

cido o "congelamento metonímico" que costumeiramente "aprisiona" as "partes", submetendo-as ao "todo", assumimos o prazer e o risco, que os rigores metodológicos possivelmente condenariam (Loraux in Abensour, 1987, p. 157), a que convida a autonomia do gai savoir de Clastres. Há como raciocinar não-dialeticamente e não há por que ceder aos ardis do entediante e desgastado movimento pendular, que nos arrasta ora para a "estrutura", ora para a "história"; ora para a "permanência", ora para a "mudança"; ora para a "sincronia", ora para a "diacronia"; ora para a "cultura", ora para a "natureza"; ora para o "masculino", ora para o "feminino"; ora para o "complexo", ora para o "nativo"; ora para a "sociedade", ora para o "indivíduo". Haverá sempre algo de "nativo" em "nós" e de "nós" no "nativo", e esta parece mesmo ser a condição de possibilidade de uma antropologia que não esvazie o potencial desestabilizador da diferença, que, por trazer em si a evidência de que tudo poderia ser e é também e ao mesmo tempo de outro modo, nos descortina ousadamente a liberdade. O que conspira já contra a cristalização do princípio de identidade, que quer que um "nativo" seja sempre e tão-somente um "nativo", a satisfazer as necessidades acadêmicas (e não apenas) de exotismo: a diferença termina aí domesticada e a eterno serviço da identidade, devolvendo a Narciso a imagem - invertida - de que ele tanto precisa. Mas o que é o princípio de identidade? Neste ponto, recorremos uma vez mais aos selvagens - sim, porque se trata sempre de nós - e valemo-nos da metafísica guarani. O que ela nos ensina em sua genealogia da infelicidade? Que as coisas, em sua totalidade, são uma e, para nós, que não desejamos isto, elas são más (Clastres, 1972-1973, p. 147). Os homens habitam uma terra imperfeita, e os guaranis nunca foram bons selvagens: residem nesta terra sim. Mas nunca deixam de sonhar com ywy mara-ey, a Terra sem Mal, o lugar do não-Um, "onde o milho cresce sozinho, a flecha traz a presa àqueles que não têm mais necessidade de caçar, o fluxo regrado dos casamentos é desconhecido, 
Gustavo B. Barbosa. A Socialidade contra o Estado...

os homens, eternamente jovens, vivem eternamente" (idem, p. 150). Os habitantes de ywy mara-ey são ainda homens, mas não apenas: são já deuses. A terra imperfeita, onde as coisas, em sua totalidade, são uma, revela-se assim como o campo do finito, do incompleto, o lugar da aplicação rigorosa do princípio de identidade: "Pois dizer que $A=A$, que isto é isto e que um homem é um homem é declarar ao mesmo tempo que A não é não-A, que isto não é aquilo e que os homens não são deuses. Nomear a unidade nas coisas, nomear as coisas segundo sua unidade, é também assinalar-lhes o limite, o finito, o incompleto" (idem, p. 149). O que é o Um, então? "[A]creditamos poder revelar, sob a equação metafísica que iguala o Mal ao Um, uma outra equação mais secreta, que diz que o Um é o Estado" (Clastres, 1974a, p. 184-5).

A que poderes terá, assim, atendido a antropologia em sua busca, sempre renovada e quase obsessiva, pelo princípio de identidade? Que efeitos ilusionistas - no entanto, plenos de repercussões - terão se perenizado dessa forma, e qual será o futuro desta ilusão? De novo, o ritornelo e, uma última vez, retornamos aos indígenas - porque continua a tratar-se de nós -, que, na eloqüência de seu silêncio, nos revelam a tautologia, entretanto, aparentemente nem sempre evidente de que um espelho é um espelho:

[T]ínhamos distribuído aos índios, que jamais os tinham visto, pequenos espelhos nomeados por eles chaã [...]. Uma meia hora, por vezes mesmo horas a fio, eles se olhavam (sobretudo os homens), o espelho ora na ponta do braço, ora sob o nariz, mudos de arrebatamento ao ver esse rosto que lhes pertencia e que não lhes oferecia, quando tentavam tocá-lo com a ponta dos dedos, senão a superfície fria e dura do chaã. (Clastres, 1972, p. 101) 


\section{Notas}

1 Este artigo resume os principais argumentos que desenvolvi em minha dissertação de mestrado, de mesmo título, apresentada ao PPGAS do Museu Nacional (UFRJ) em 2002. Direciono àquele trabalho eventuais leitores mais curiosos ou críticos. Registro aqui brevemente meus agradecimentos a meu orientador, professor Marcio Goldman, aos integrantes da banca, professores Eduardo Viveiros de Castro e Tania Stolze Lima, e ao colega e amigo, Aristóteles Barcelos Neto, cuja insistência fez este artigo ganhar corpo.

2 É como Deleuze descreve o teatro de Carmelo Bene (Deleuze e Bene, 1978, p 97). Os comentários que se seguem baseiam-se, em grande parte, nas observaçôes de Deleuze sobre o Ricardo III de Bene (idem, p. 85 et passim).

3 Para instigante debate a respeito da atualidade ou obsolescência do conceito de "sociedade" - e de sua excrescência, o de "indivíduo" -, ver "The Concept of Society is Theoretically Obsolete" (Ingold, 1996, p. 55-98).

4 Não tenho, de maneira alguma, a intenção de desrespeitar aqui um dos cânones da etnologia, por meio da imposição apressada ao "nosso nativo" - no caso, o próprio Clastres - de conceitos que lhe são estranhos. Antes, nossa aposta é que certa concepção de "socialidade", em operação, existe já em sua etnografia.

5 Sobre as "raízes", as "radículas" e os "rizomas" - de que nos utilizamos para dividir este trabalho em partes -, ver Deleuze e Guattari (1980, vol. 1, p. 13 et passim; vol. 5, p. 220 et passim).

6 Será assumidamente sumário esse exercício, pois sua finalidade não é a de proceder a um ambicioso recenseamento crítico das obras de Durkheim e Lévi-Strauss, mas antes a de marcar a diferença - e a "novidade" - do conceito de "sociedade" de Clastres em relação aos daqueles autores.

7 A declaração de Lady Thatcher - de acordo com a qual "não existe sociedade; somente homens e mulheres individuais" - bem ilustra o ponto. A frase trai o credo individualista da primeira-ministra, que justificará o desmonte do Welfare State no Reino Unido, em curiosa e nada ingênua inversão de Clastres, pois se trata aí do Estado contra a sociedade.

8 Já que "o diálogo [...] não vive apenas de concordâncias" (Loraux in Abensour, 1987, p. 159), é precisamente quando Clastres recorre, de maneira explícita, ao pensamento grego como origem do Um, do Estado, que o historiador da Grécia 
deixa de reconhecer, nas páginas do antropólogo francês, um universo que lhe é familiar (idem, p. 159 et passim). À "insurreição ativa contra o império do Um" de seus índios, Clastres opõe a suposta "nostalgia contemplativa do Um", que impõe aos gregos, como se, ao pensar sobre o mesmo, o Um, os profetas selvagens e os gregos antigos lhe atribuíssem valores trocados: negativo, no primeiro caso; positivo, no segundo. Para Loraux, ao querer encontrar em Atenas a origem da metafísica política ocidental - fundada na diferença entre dominantes e dominados, considerada como imanente à sociedade -, Clastres fabrica para si uma Grécia sob medida. A política na Grécia antiga - ensina Loraux - faz-se entre iguais, segundo o modelo da arkhé, que, ao promover uma rotação das tarefas da administração da polis entre os cidadãos, permite que todos e cada um, a seu tempo, comandem e obedeçam. Se os gregos de fato terão colocado a política sob o domínio do Um, fizeram-no não no sentido de inaugurar uma hierarquia entre dominantes e dominados - na verdade, inexistente - mas, opina Loraux, no de dissimular a potencialidade ameaçadora do dois. Ao submeter sua política ao império do Um, os gregos procuram preservar a indivisão no seio da polis e evitar a emergência do dois (idem, p. 163). Já os Guarani, segundo Clastres, cultivam o dois como o número da Terra sem Mal, que lhes facultaria ser homens e deuses ao mesmo tempo. Em certo sentido, Loraux inverte a essa altura o raciocínio de Clastres, ampliando-o e subvertendo-o: à "insurreição ativa contra o dois" de seus gregos, opõe a "nostalgia contemplativa do dois" dos índios de Clastres. E curiosamente apenas contemplativa, conforme observa Loraux com argúcia: diante do dois bem real, manifestado na inescapável existência dos dois sexos, os índios de Clastres optam por refugiar-se no monadismo do Um, que faz com que um homem obrigatória e inapelavelmente seja um homem; um caçador seja um caçador; A seja A, tornando Chachubutawachugi o homem que não consegue caçar e que, no entanto, quer permanecer no universo da masculinidade, ridícula figura, porque obstinada em ocupar um lugar a meio-caminho entre o masculino e o feminino, que, a rigor, não existe (Clastres, 1972, p. 217).

9 Sobre as galladas, "formas próprias" - anti-Estado, diríamos nós - de organização dos "bandos" de moleques de Bogotá, ver Meunier (1977).

10 Cito as passagens em questão: "Não é a troca que é primeira, é a guerra, inscrita no modo de funcionamento da sociedade primitiva. A guerra implica a aliança, a aliança suscita a troca (entendida não como diferença do homem e do animal, 
como passagem da natureza à cultura mas, é claro, como desdobramento da socialidade da sociedade primitiva, como livre jogo de seu ser político). É através da guerra que se pode compreender a troca e não o inverso" (1977b, p. 200; grifo meu). E: "Levando a sério, por um lado, as sociedades primitivas e, por outro, o discurso etnológico sobre essas sociedades, eu me pergunto por que são sem Estado, por que o poder não se encontra separado do corpo social. Convenço-me pouco a pouco de que esta não-separação do poder, de que esta não-divisão do ser social não são devidas a um estado fetal ou embrionário das sociedades primitivas, a um inacabamento ou incompletude, mas dizem respeito a um ato sociológico, a uma instituição da socialidade como recusa da divisão, como recusa da dominação. Se as sociedades primitivas são sem Estado, é porque são contra o Estado" (1977a, p. 153-4; grifo meu).

11 Se aqui nos ocupamos, sobretudo, com a forma como o conceito de socialidade possui rendimento analítico na obra de Clastres, isto não elimina - antes pelo contrário - a pergunta complementar: o que a obra de Clastres poderia acrescentar ao conceito de socialidade? As respostas, porém, exigiriam um artigo suplementar.

12 A frase inspira-se em Deleuze e Guattari; também eles interessados em acompanhar de que maneira as diversas máquinas sociais, em função dos agenciamentos que operam, produzirão formas de subjetivação específicas - veja-se, por exemplo, o capítulo "Selvagens, bárbaros e civilizados" de O Anti-Édipo - capitalismo e esquizofrenia (1972).

13 Aqui, disporei de espaço apenas para indicar como um guerreiro se faz. Para indicação de como o "desejo" de cada um e a "vontade" do grupo - sem nenhuma externalidade entre si - atuam na constituição dos caçadores, dos maridos e dos homens e das mulheres adultos, veja Barbosa (2002, p. 78-84).

\section{Bibliografia}

ABENSOUR, M. (org.)

1987

L'esprit des lois sauvages - Pierre Clastres ou une nouvelle anthropologie politique, Paris, Seuil. 
Gustavo B. Barbosa. A Socialidade contra o Estado...

BARBOSA, G.

2002

A socialidade contra o Estado: a antropologia de Pierre Clastres, dissertação de mestrado, PPGAS/Museu Nacional/UFRJ.

CARRILHO, M. M. (org.)

1976 Capitalismo e esquizofrenia - dossier Anti-Édipo, Lisboa, Assírio \& Alvim.

CARTRY, M.

1978 "Pierre Clastres", Libre 4: 40-49.

CHÂTELET, F.

1976

"La question de l'histoire de la philosophie aujourd'hui", in GRISONI, D. (org.), Politiques de la philosophie, Paris, Bernard Grasset, p. 29-53.

CHÂTELET, F. \& PISIER-KOUCHNER, E.

1983 As concepçóes políticas do século XX. História do pensamento político, São Paulo, Zahar.

CHÂTELET, F.; DUHAMEL, O. \& PISIER-KOUCHNER, E.

1982

História das idéias políticas, Rio de Janeiro, Zahar.

CLASTRES, P.

1962 "Échange et pouvoir: philosophie de la chefferie indienne", L'Homme II (1), (SCE).

1963 a "Indépendance et exogamie", L'Homme III (3), (SCE).

1963b (\& Sebag, L.), "Cannibalisme et mort chez les Guayakis", Revista do Museu Paulista XIX: 174-81.

1964 "Compte rendu de Mission chez les indiens Guayaki (Paraguay)", L'Homme IV (2): 122-125.

1966 "L'Arc et le Pannier", L'Homme VI (2), (SCE).

* Indicamos as datas originais das publicaçôes dos artigos de Clastres. Muitos deles foram republicados em La Société contre l'État - Recherches d'Anthropologie Politique (Paris, Minuit, 1974) e em Recherches d'Anthropologie Politique (Paris, Seuil, 1980), aos quais me refiro, como SCE ou RAP, respectivamente, colocados entre parênteses ao final da citação de cada artigo. 
Revista de Antropologia, São Paulo, USP, 2004, v. 47 no 2.

$1967 \mathrm{a}$

$1967 \mathrm{~b}$

$1967 \mathrm{c}$

$1968 \mathrm{a}$

$1968 b$

$1969 \mathrm{a}$

$1969 \mathrm{~b}$

1970

$1971 \mathrm{a}$

$1971 b$

1972

$1972-1973$

$1973 \mathrm{a}$

$1973 b$

1973 c

$1974 \mathrm{a}$

$1974 \mathrm{~b}$

$1974 \mathrm{c}$

$1974 d$

$1976 \mathrm{a}$

$1976 b$

$1976 \mathrm{c}$

$1977 \mathrm{a}$

$1977 \mathrm{~b}$

$1977 \mathrm{c}$

1978

$1980 \mathrm{a}$

"Mission au Paraguay et au Brésil", L'Homme VII (4): 101-8.

"Ethnologie des indiens guayaki: la vie sociale de la tribu”, L'Homme VII (4): 5-24.

“De Quoi Rient les Indiens?”, Les Temps Modernes 253, (SCE)

"Ethnographie des Indiens Guayaki". Journal de la Société des Américanistes LVII: 8-61.

"Entre silence et dialogue", L'Arc 26. Republicado em BELLOUR, R. \& CLÉMENT, C. Claude Lévi-Strauss, Paris, Gallimard, 1979, p. 33-8.

"Copernic et les sauvages", Critique 270, (SCE)

"Une ethnographie sauvage", L'Homme IX (1), (RAP).

"Prophètes dans la Jungle", in Echanges et communications (Mélanges offerts à Claude Lévi-Strauss à l'occcasion de son 60e. aniversarie), Paris-La Haye, Mouton, (SCE).

"Le dernier cercle", Les Temps Modernes 298, (RAP).

"Le clou de la croisière", Les Temps Modernes 299-300, (RAP).

Chronique des Indiens Guayaki - Ce que savent les aché, chasseurs nomades du Paraguay, Paris, Plon, (1991).

"De l'Un sans le Multiple", L'Ephémère 19-20, (SCE)

"Eléments de démographie amérindienne", L'Homme XIII (1-2), (SCE)

"Le devoir de la parole". La Nouvelle Revue de Psychanalyse 8, (SCE).

"De la torture dans les sociétés primitives", L'Homme XIII (3), (SCE)

"La Société contre l'État", (SCE).

La Société contre l'État - recherches d'anthropologie politique, Paris, Minuit (1996).

Le grand parler, Paris, Seuil.

"De l'Ethnocide", in Encyclopaedia Universalis, Paris, Universalia, (RAP).

"La question du pouvoir dans les sociétés primitives", Interrogations 7, (RAP).

"Liberté, malencontre, innomable", in LA BOÉTIE, E. Le discours de la servitude volontaire, Paris, Payot, (1576), (RAP).

"L'économie primitive", in SAHLINS, M. Age de Pierre, Age d'Abondance, Paris, Gallimard, (RAP).

"Le retour des lumières", Revue Française de Science Politique 1, (RAP).

"Archéologie de la violence: la guerre dans les sociétés primitives", Libre 1, (RAP).

"Malheur du guerrier sauvage", Libre 1, (RAP).

"Les marxistes et leur anthropologie", Libre 3, (RAP).

"Mythes et rites des indiens d'Amérique du Sud", (RAP). 
Gustavo B. Barbosa. A Socialidade contra o Estado...

1980b Recherches d'Anthropologie Politique, Paris, Seuil.

$1978^{* *} \quad$ A Sociedade contra o Estado - pesquisas de antropologia politica, São Paulo, Livraria Francisco Alves, (1988). Tradução de Theo Santiago. Republicação: São Paulo, Cocac \& Naify, 2003.

1982** Arqueologia da violência - ensaio de antropologia politica, São Paulo, Brasiliense. Tradução de Carlos Eugênio Marcondes de Moura. Republicação: São Paulo, Cosac \& Naify, 2004.

1985* Crônica dos indios Guayaki - o que sabem os Aché, caçadores nômades do Paraguai, Rio de Janeiro, Editora 34. Tradução de Tânia Stolze Lima e Janice Caiafa.

$1990^{* *} \quad$ A fala sagrada - mitos e cantos sagrados dos indios Guarani, Campinas, Papirus. Tradução de Nícia Adan Bonatti.

DELEUZE, G. \& BENE. C.

1978 Superpositions, Paris, Minuit, (1979).

DELEUZE, G. \& GUATTARI, F.

1972 O Anti-Édipo - capitalismo e esquizofrenia, Rio de Janeiro, Imago, (1976).

1980 Mil Platôs - capitalismo e esquizofrenia, São Paulo, Editora 34, (1997).

FOUCAULT, M.

$1969 \quad$ L'archeologie du savoir, Paris, Gallimard.

GAUCHET, M.

1977 "Pierre Clastres", Libre 4: 55-68 (1978).

GELL, A.

1999

"Strathernograms: or the semiotics of mixed metaphors", in GELL, A. The art of anthropology, Londres/New Brunwick, NJ/The Athlone Press.

GOLDMAN, M.

1994 Razão e diferença - afetividade, racionalidade e relativismo no pensamento de LévyBrubl, Rio de Janeiro, Grypho/UFRJ.

1999 A experiência de Lienhardt: uma teoria etnográfica da religião. Religião e Sociedade 19(2): 9-30.

** Também foram examinadas as traduçôes brasileiras dos livros de Clastres, das quais me utilizei em praticamente todas as citaçôes. 
GOLDMAN, M. \& LIMA, T.

2001 "Pierre Clastres, etnólogo da América”, Sexta-Feira 6: 291-309.

INGOLD, T. (ed.).

1996

Key debates in anthropology, Londres, Routledge.

LA BOÉTIE, E.

1576 Le discours de la servitude volontaire, Paris, Flammarion, (1983).

LÉBRUN, G.

1984 O que é poder?, São Paulo, Brasiliense.

LÉVI-STRAUSS, C.

1947 "La Sociologie Française", in GURVITCH, G. La Sociologie au XIXe. Siècle: les Études Sociologiques dans les Différents Pays, Paris, PUF, p. 513-45.

1950 "Introduction à l'Oeuvre de Marcel Mauss", in MAUSS, M. Sociologie et Anthropologie, Paris, Quadrige/PUF: IX-LII, (1997).

1967 As estruturas elementares do parentesco, Petrópolis, Vozes, (1982).

LIZOT, J.

1976

O círculo dos fogos. Feitos e ditos dos índios Yanomami, São Paulo, Livraria Martins Fontes, (1988).

LUKES, S.

1973

Émile Durkheim - His Life and Work - A Historical and Critical Study, Middlesex, Penguin Books, (1981).

MEUNIER. J.

1977

Os Moleques de Bogotá, Rio de Janeiro/São Paulo, Difel, (1978).

ORTNER, S. B.

1984

"Theory in Anthropology since the Sixties", Comparative Studies in Society and History 26(1): 126-66.

SIMONIS, Y.

1968

Claude Lévi-Strauss ou la passion de l'inceste - introduction au structuralisme, Paris, Aubier-Montaigne. 
Gustavo B. Barbosa. A Socialidade contra o Estado...

STRATHERN, M.

1988

The Gender of the Gift - Problems with Woman and Problems with Society in Melanesia, Berkeley/Los Angeles/Londres, University of California Press, (1990).

VARGAS, E.

Antes tarde do que nunca - Gabriel Tarde e a emergência das ciências sociais, Rio de Janeiro, Contra Capa.

VIVEIROS DE CASTRO, E.

1996

"Society", in BARNARD, A. \& SPENCER, J. (eds.), Encyclopaedic Dictionary of Social and Cultural Anthropology, Londres, Routledge, p. 514-2.

ABSTRACT: Clastres "de-substantializes" the State, which is not "the Elysées, the White House, the Kremlin", but "an actualization of a relation of power". There is no reason, therefore, to believe that, in a Durkheimian mood, he has reified the society. Even though he does not make use of the concept, it seems to us that there is already a "sociality" in Clastres: thus, the sociality against the State. In the three divisions of this study, we show the role the "society", the "State" and the "against" play in Clastres' writings. This way, we aim to demonstrate that, in his ethnography, we find indications as to how to deal with some of the dilemmas of anthropology, such as: How can we avoid the methodological individualism without being grasped by a transcendental holism or vice-versa? How can we erect models of intentionality with no subject? How can we conceive of social relations with no society? And finally, how does the "objectivity" of sociality work through the "subjectivity" of persons-in-interaction?

KEY-WORDS: Anthropological Theory, Political Anthropology, Pierre Clastres, Sociality. 